http:/ /dx.doi.org/10.1590/0104-07072017002660015

\title{
BETTER OFF AT HOME: SAFETY DEVICE
}

\author{
Stefanie Griebeler Oliveiraㅁ, Maria Henriqueta Luce Kruse²
}

1 Ph.D. in Nursing. Professor,e Nursing Department, Universidade Federal de Pelotas. Pelotas, Rio Grande do Sul, Brasil. E-mail: stefaniegriebeleroliveira@gmail.com

2 Ph.D. in Education. Professor, School of Nursing, Universidade Federal do Rio Grande do Sul. Porto Alegre, Rio Grande do Sul, Brasil. E-mail: kruse@uol.com.br

\begin{abstract}
Objetive: to problematize the home care proposed by the Melhor em Casa Program as a safety device for understanding knowledge and conditions of possibility that support its discoursive network.

Method: it is a study of genealogical inspiration about home care. The empirical material was constituted by legal documents about the theme, published in the Diário Oficial. The extracts that supposingly had the power to extract truth were organized in a spreadsheet. The analytic units were constructed, and instruments proposed by Foucault, such as power, biopolitics and device, were used for document analysis. Results: two analytic categories were elaborated: "From hospital to home", and "Home care: safety for the patient or for the State?".

Conclusion: Home care, as a security device, proposes home as a safer and better place for the patient, who is close to the family, with no risk of hospital infection, cared by the health team, with the necessary technology.
\end{abstract}

DESCRIPTORS: Home care services. Nursing. Documents.

\section{MELHOR EM CASA: DISPOSITIVO DE SEGURANÇA}

\section{RESUMO}

Objetivo: problematizar a atenção domiciliar como dispositivo de segurança, proposta pelo Programa Melhor em Casa como dispositivo de segurança, para conhecer os saberes e as condições de possibilidade que sustentam sua rede discursiva.

Método: estudo de inspiração genealógica sobre a atenção domiciliar. O material empírico foi constituído por documentos legais sobre o tema, publicados no Diário Oficial. Os excertos que teriam poder de fazer circular verdades foram organizados em planilha eletrônica. As unidades analíticas foram construídas, sendo utilizadas para a análise documental ferramentas propostas por Foucault, tais como: poder, biopolítica e dispositivo.

Resultados: foram elaboradas duas categorias analíticas: "Do hospital para o domicílio" e "atenção domiciliar: segurança para o paciente ou ao Estado?"

ConclusãoA atenção domiciliar como dispositivo de segurança constitui a casa como um lugar mais seguro e melhor para o paciente que fica próximo da família, sem risco de infecção hospitalar, recebendo atendimento de equipe que propiciará a tecnologia necessária.

DESCRITORES: Serviços de assistência domiciliar. Enfermagem. Documentos.

\section{MEJOR EM CASA: DISPOSITIVO DE SEGURIDAD}

\section{RESUMEN}

Objetivo: discutir la atención domiciliaria como dispositivo de seguridad, propuesto por el Programa Melhor em Casa como un dispositivo de seguridad, para obtener información sobre los conocimientos y las condiciones de posibilidad que sustentan su red discursiva.

Método: estudio de inspiración genealógica sobre la atención domiciliar. El material empírico fue constituido por documentos legales sobre el tema, publicados en el Diario Oficial. Los fragmentos que tendrían el poder de hacer circular verdades fueron organizados en una planilla electrónica. Las unidades analíticas fueron construidas, siendo utilizadas para el análisis documental herramientas propuestas por Foucault, tales como: poder, biopolítica y dispositivo.

Resultados: fueron elaboradas dos categorías analíticas “Del hospital para el domicilio" y, "La atención domiciliar: ¿seguridad para el paciente o para el Estado?".

Conclusión: la atención domiciliar como dispositivo de seguridad constituye a la casa como un lugar más seguro y mejor para el paciente que se queda cerca de la familia, sin riesgo de infección hospitalaria, recibiendo atención por parte del equipo que propiciará la tecnología necesaria.

DESCRITORES: Servicios de atención de salud a domicilio. Enfermería. Documentos. 


\section{INTRODUCTION}

In recent years, home care has been targeted at patients who require palliative care. ${ }^{1-2}$ It is considered that this type of care, aimed at people with life-threatening ILLNESS, contributes to the promotion of comfort and satisfaction of the needs of the dying due to the environment being more favorable for patient care. ${ }^{3}$ Thus, the Ministry of Health instituted in 2011 the Melhor Em Casa Program, ${ }^{4}$ with the motto: "the safety of the hospital in the comfort of your home." Security and comfort: a wonderful combination, no? Who wouldn't want it? Safety reminds us of the feeling of being protected from risks and losses. Comfort relates to the state of relief, of well-being. When such a slogan appears, we begin to question it, reflecting on its senses and what could be thought from it.

How and when does health care take place in the patient's home? Since the Middle Ages, there have been displacements in the places of treatment and in the cure of diseases..$^{5-6}$ At that time, hospitals already existed to provide assistance to the poor and sick who represented a threat to society and should therefore be excluded from public circulation. These places did not aim at the healing and care of the sick, but rather the salvation of the soul, since the subjects of exclusion were already considered dead beings. In this way, the hospital was considered a synonym for dying. ${ }^{5}$

In discussing the birth of Social Medicine, the philosopher Michel Foucault explains that the West organized disease control in two models: leprosy and plague. In the first, sick people were withdrawn from circulation and placed outside the city. In the second, people were to remain at home, the city being divided into neighborhoods under the responsibility of an authority who ran the streets, surveying the inhabitants of the city, calling them to appear at the window of the house, whether they were alive or dead. These records were forwarded to the district chief, who in turn referred them to the higher authority. In this way, not only the surveillance but the centralization of the registers was also obtained. ${ }^{6}$ In relation to the birth of the hospital, Michel Foucault points out that such an institution was organized and medicalized in the mid-eighteenth century and this had little to do with the well-being of the patients, but with the annulment of the negative effects that this environment produced, due to the disorder of the hospitalizations, with the possibility that the diseases spread to the other inhabitants of the city, leading to an economic disorder. ${ }^{5}$
The Melhor em casa Program establishes guidelines for the organization of home care and defines it as a form of substitutive or complementary health care, which is characterized by actions to promote health, prevent and treat diseases and rehabilitation provided at home, with guarantee of continuity of care and integration into the health care networks. ${ }^{4}$ Faced with this event, considering the discursive network that regulates and justifies it, as well as documents of home care and also of the Ministry of Health and the World Health Organization, we believe it is possible to change the lens, blur the boundaries, change the focus, propose new visions, and another problematization.

For us, who are nurses and teachers, to understand how the policies were formed which invented the care of people in their home, and how these official discourses constitute health and illness in the home of people who need care, implies to go against the discourse, so as to see its functioning, its purposes, doubting its truisms. We justify the term "counter" because we understand that, as health professionals, we are considered state agents ${ }^{6-7}$ who perform bio political interventions that guarantee the lives of people. Instead of saying that it is "better at home", as the studies say,,$^{2-3,8-9}$ this study of genealogical inspiration placed the question of genesis and continuities under suspension, not definitively refusing them, but shaking the stillness from which we accept them, in addition to showing that they are not self-justifiable but that they are the effect of a construction whose rules must be known and the justifications controlled. ${ }^{10}$

In view of this, we pretended with this study to problematize the home care proposed by the Melhor em Casa Program as a security tool/device, to understand the knowledge and the conditions of possibility that support its discursive network. We believe that there is a history of exclusion of those still sick in the hospital environment and that there are different historical and cultural moments and conditions of possibility for a public policy to be configured and invented in the discursive network of the Melhor em Casa Program, and that certain truths have been produced and organized to support this practice within the scope of the Brazilian Unified National Health System (SUS).

\section{METHOD}

A study of genealogical inspiration inserted in the poststructuralist strand of Foucauldian inspiration whose object is home care at the end of the 20th century and the beginning of the 21 st century. Gene- 
alogy seeks to establish a correspondence between the meaning of the present and the immediate past, as well as to describe the history of interpretations about an object. ${ }^{11}$ Interpretation cannot be understood as the unveiling of a hidden meaning, since the more one interprets, the less the meaning of a text is. Genealogy searches for discontinuities where continuities have been established. ${ }^{12}$

The empirical material consisted of legal documents referring to home health care, with emphasis on home hospitalization, published in the Diário Oficial da União (DOU). This material was found on the Jus Brasil website (http:/ / www.jusbrasil.com.br/ diarios), and the search was carried out in May 2013. The excerpts selected were transcribed to a spreadsheet in Excel, in which the reference, excerpt, the speaker and limitation procedures were informed.

The next phase consisted of the elaboration of the analytical units, based on the relations established between the statements and historical periods. The documents analyzed are identified and coded with the letter D and a number which follows the order of the documents (eg D1, D2 ...) according to table 1 .

\section{Table 1- Relationship and codification of documents analyzaed}

\begin{tabular}{|l|l|}
\hline Code & Document \\
\hline D1 & Ordinance N 1.892, 18th of December 1997 \\
\hline D2 & Ordinance N 2.416, 23rd of March 1998 \\
\hline D3 & Ordinance N 2.529, 19th of October 2006 \\
\hline D4 & Ordinance N 1.395, 9th of December 1999 \\
\hline D5 & Ordinance N 2.527, 27th October 2011 \\
\hline D6 & Ordinance N963, 27th of May 2013 \\
\hline
\end{tabular}

To guide the documentary analysis and to compose the study, Michel Foucault's tools were used as a way to "hammer" the discourses that circulate regarding home care, including: power, bio-politics and device. Power governs the statements and the way in which they are organized among themselves to constitute a set of propositions that are scientifically acceptable. It is not a matter of knowing which power acts from outside, but which effects power to circulate between statements, and how and why in certain moments it changes and in others it does not. What causes it to maintain power and to accept it is that, it is not a force that says no, but which induces pleasure, forms knowledge and produces discourse, and is considered a productive network. ${ }^{13}$

Biopolitics deals with the population as a political problem, since it consists of a set of processes such as birth, morbidity, and mortality, which were the objects of knowledge and a control target tied to the economic and political problems of each era. Biopolitics consists of a strategy to rationalize the problems of government practice, using statistics, not to change something in the individual, but to intervene in what is determinant in the population, in what is possible to establish a regulation, in order to bring balance, homeostasis, ensuring compensations, providing safety. ${ }^{14}$

The device consists of a heterogeneous set that encompasses discourses, institutions, architectural organizations, regulatory decisions, laws, administrative measures, scientific statements, philosophical propositions, moral, philanthropic, ie, the said and the unsaid composes the device. It is the network that can be woven among these elements.

This research was not submitted to the Research Ethics Committee, due to the empirical material being composed of public domain documents whose "authors" are responsible for what is said and written, for the place they occupy, for meeting certain requirements and being qualified to do so. The word "authors" is enclosed in quotation marks, because we believe that the author does not exist, because we understand that this is only a function within the discourse. ${ }^{16}$

\section{RESULTS AND DISCUSSION}

The analysis of the documents made it possible to organize two analytical categories "From hospital to home" and "Home care: safety for the patient or for the State?" 


\section{From hospital to home}

The first ordinance that instituted home hospitalization under SUS was published in 1997 and presents the objectives of this modality of care in the health system, especially the expansion of hospital care and the qualification of care: it incorporates the Internação Domiciliar ao Sistema Único de Saúde. The Minister of Health, in the use of its legal attributions, and considering that home hospitalization extends to the conditions of hospital attendance and the quality of the assistance of the Brazilian Unified $\mathrm{Na}$ tional Health System, it states: Article 1 To incorporate the Sistema de Informaçôes Hospitalares do Sistema Único de Saúde - SIH/SUS ... (D1).

A new modality of care was born: hospitalization at home. To internalize would be the act of institutionalizing a person, but, in this case, institutionalizing at home. Thus, this legal discourse invents the home as an institution, proposing that patients can stay in their homes, expanding hospital care and the quality of SUS care. We believe that this strategy of expanding hospital care was a condition of possibility for the appearance of hospitalization.

In our analysis we found other conditions of possibility for the appearance of home care, in this format of home hospitalization, which is the long-term care directed to elderly patients, patients with chronic-degenerative conditions and advanced cancer. Also, we note that the expression hospital care expansion (D1) was replaced in the following decrees by dehospitalization (D2; D3). The first one established requirements for hospital accreditation and criteria for inclusion of patients in this care modality, and the second one set out the Política de Internação Domiciliar in its appendix.

Considering that home hospitalization provides the humanization of care and follow-up of chronically hospital dependent patients, and considering that the adequate dehospitalization provides a greater contact of the patient with the family favoring its recovery and reducing the risk of hospital infections [...]. The following are priority conditions for home hospitalization: patients aged over 85 years [...]; Patients with chronic conditions [...]; Patients affected by trauma with fracture or recovering from osteo-articular disease; Patients with malignant neoplasms (D2); [...] numerous health institutions are seeking [...] practices aimed at care with variable care intensities, carrying out the therapeutic intervention inside the home of the user as a common characteristic. The analysis of these experiences demonstrates the existence of at least four groups of objectives [...] that establish the center of its area of action: - de-hospitalization of unnecessary events generated by lack of support or by issues related to the process of social exclusion; - "early discharge" processes, demonstrating the economics of the hospital process [...]; - the search for longer periods free of hospital complications in chronic patients, with a history of recurrent readmissions; And - a humanized therapeutic process to reduce suffering in a palliative care situation, where pain relief and, and why not to say that a good death is the object of the health work process (D3).

The discourse of de-hospitalization, in these ordinances, makes use of strong arguments that it is difficult to disagree: humanization in care, contact with the family, favoring recovery, reduction of suffering, good death, and reduced risk of nosocomial infection. The change in the expression "hospital care expansion" (D1) for de-hospitalization (D2; D3) makes the intention of these policies explicit: to de-hospitalize. In other words, it proposes the saving of human and material resources of the hospital institution with the displacement of the patient to the home. The hospital offers multi-professional health teams and necessary equipment to perform home care, with the objective of reducing expenses, since home hospitalization does not require the health professionals' vigilance and the maintenance of the patient for 24 hours, as which occurs in the hospital space. The patient returns to his home, being protected from hospital infections, and the family performs care, assuming the institutional role of promoting recovery, comfort and relief of suffering, with the support and control of the multiprofessional team of home care.

Such discourses have effects on health professionals, since they form a scientific knowledge that crosses them. The four axes (D3), called dehospitalization, prevention of early discharge, prevention of hospital admissions and humanized therapeutic process, come from discourses that circulate frequently in the texts of the area ${ }^{17-18}$ and make the elaboration of the policies that determine the reduction of hospital expenses feasible with the hospitalization at home. The policy discourse ensures that the expansion of hospital services to the patient's home will avoid readmissions in a short period of time, and that the family will be able to obtain a more comfortable, humanized care with reduction of suffering, without risk and, who knows, a good death at home. These ideas of a good death at home, proximity to the family in times of suffering already circulate in media, as a study shows, ${ }^{19}$ where the magazines circulate the idea that dying well is dying at home. In this logic, the family and palliative care, which are connected together to minimize damages to the subject and 
boost health investments, especially when it comes to optimizing hospital beds.

The economy of the material and human resources of the hospital determines the return of the patient to coexist with the family, protected by justifications of qualification of the attention by the principles of the humanization and the reduction of the exposure to the risk of hospital infections. But what would this humanization of health be? An analysis of the discourse of the humanization of health ${ }^{20}$ shows that, first, in the 1970's, the discourse turned to practices of loving your neighbor, concern with spiritual issues, tolerance, benevolence; In the second instant, in the 1980's and 1990's, humanization was focused on working conditions, motivation of health teams, nursing process implementation, interaction with the family and post-hospital discharge guidelines. In the third instant, in addition to the reproduction of previous meanings, humanization discourses contemplated the emergence of technologies such as interpersonal communication, recognition of people's autonomy, the right to information, respect for decision-making and the link between team and user. In this sense, the humanization discourse in health supports the purposes of de-hospitalization, since it also opposes the hard technology and hospital model, proposing interrelationships between health professionals and users, as well as the inclusion of the family in patient care.

Humanization can also be seen as a governance strategy, since professionals must govern the agony and take care of the relatives of the patient who is at home, establishing a relationship of trust, guiding and supporting the difficulties and doubts. In addition, they should establish partnerships with the caregivers of older people, in order to govern better: the partnership between heal th professionals and caregivers should enable the systematization of the tasks which are carried out, [...] at home. Privileging those related to health promotion, to the prevention of disabilities and to the maintenance of the functional capacity of the elderly who is dependent on their caregiver, thus avoiding, as far as possible, hospitalizations, isolation and other forms of segregation and isolation (D4); The caregiver is a relevant actor for effective home care and should be considered as an important element in the articulation and resource allocation and efforts to achieve the formulated therapeutic projects (D3).

Partnership between health professionals and caregivers and valorization of the role of the caregiver as executor of home care are statements that circulate in the discourses of home care, addressed to health professionals, since they do not address the caregiver. Thus, health professionals are manufactured in this logic of home care, with the function of valuing the caregiver, assisting the State in the production of this useful subject, who plays a relevant role in maintaining the patient at home. In this sense, home care has political character to govern the populations, especially the elderly, with chronic-degenerative conditions, cancer patients, also including family members who will be caregivers. The professionals are constituted by such discourses that function as an instrument of biopolitics, as well as how to operate it.

Is de-hospitalization an indication of a hospital crisis? Is this a further sign of the shift from a disciplinary society to a controlling society? Some characteristics of the control society began to appear, especially after World War II, with the crises by means of confinement, when we began to cease being a disciplinary society. We are in a generalized crisis by means of confinement, spaces of excellence of the disciplinary society, like the hospital. There is a shift from disciplinary society to control society. The disciplinary society was possible with the organization of the great means of confinement: family, school, army, factory, hospital and prison. The ideal design of these means of confinement was to concentrate, to distribute in spaces and times, composing a productive force that is greater than the sum of its elements.

In economic and political terms, it is necessary to devise necessary reforms, new biopolitical strategies to manage biological processes, such as chronic morbidity and longevity. In this sense, we think that the crisis of the hospital has not shaken its function of treatment and cure. Its crisis derives from the increase in demands due to the changes in health care, especially the technology that has invaded it, which occurred due to the increase in the chronic-degenerative conditions that need to be circumvented with home care.

Caring for the patient in these conditions often requires only low technology, and, as a result, arguments for the release of hospital bed for high technology use have become accepted. The health team moved the patient to their home to keep their there, so as to provide beds for other patients who can take advantage of this space. The displacement of the patient to the home involves the human and material resources necessary to perform the care characterizing the control technology, once the patient will have a medical record that will be easily located and accessed. There are no fences defined in this movement. They are the control societies replacing the disciplinary societies. 


\section{Home care: safety for the patient or the State?}

In the 2011 directive, which redefines home care under SUS, dehospitalization appears in another way, with the purpose of reorganizing the work process of the teams in order to reduce the hospital demand, but maintains the objectives already mentioned in the other regulations: Article 3. Home Care aims to reorganize the work process of the teams that provide home care in primar, outpatient and hospital care, with a view to reducing the demand for hospital care and/ or reducing the period of stay of hospitalized users, the humanization of deinstitutionalization and the increase in the autonomy of users (D5).

We thought it would be interesting to note that in the publication of this ordinance, the expression "Melhor em Casa" only appears in the booklet ${ }^{22}$ which was published to guide health professionals. In the 2013 ordinance, the Melhor em Casa Program already appears (D6). Moreover, we noticed that home care can be carried out in primary care, outpatient and hospital care, unlike previous ordinances (D1, D2, D3), which directed this modality of care to the hospital. All in all, the relationship with the hospital is maintained because the motto "the safety of the hospital in the comfort of your home" gives the impression that the patient and the family will be assured by this form of care at home. Security refers to the team that will visit and accompany the patient, with their meticulous rituals, technological tools, knowledge and powers. Comfort refers to the "home sweet home", that family space, the place where "freedom" seems to exist. This freedom is only for the patient, as identified in the study, ${ }^{8}$ because, in the caregivers' view, home hospitalization allows the patients to have freedom in relation to hours of hygiene, feeding, medication, but imprisonment and deprivation for themselves, being the opposite of hospital admissions. In these hospital admissions, the prisoner is the patient, and the caregiver is free to leave the care and return, since it is the team that takes care in this confinement.

Other studies showed that home care was perceived as care provided in a favorable environment, due to the proximity of family and family environment. ${ }^{2,8-9}$ However, this opinion is not unanimous and may be related to the economy of each country, this can be seen in a study ${ }^{23}$ which showed that the patients present better results when hospitalized, due to the government providing the treatment. Such results in the hospital environment may be related to the food shortage faced by patients when they are in their homes.

Would it be a return to the arguments used by the State, in the medicine of species, as Foucault puts $\mathrm{it}^{24}$ that the patient should be cared for within the family, once there is spontaneous care, a testimony of affection, a desire for healing? No. Neither spontaneous care, nor desire for healing, because in chronic conditions or outside of therapeutic possibilities there can be no desire for healing. Care is not spontaneous because the team prepares the caregiver to perform them. Maybe it only affects, but it could be reduced when the caregiver is overworked. ${ }^{8,25}$

Foucault ${ }^{4}$ begins one of his texts saying that the hospital was not reorganized in favor of the patients, but to prevent the others from the diseases which could be produced in that institution. Thus, it can be affirmed that home care was invented as an economic and political way to govern the biological processes of the population, such as morbidity and mortality. It is born from the economic need of the hospital, since chronic patients tend to have readmissions. If the disease is chronic there will be no cure, then there will be no need to admit the patient to receive curative treatment. They can be taken care of at home, receiving the attention of a team that will attend to them according to their needs. Linked to this discourse of the hospital's economic need, there are changes in the health and disease processes of the population, such as the increase in chronic diseases and life expectancy.

To function as a safety device, home care needs to be linked to the health services network, through health discourses, in order to capture more individuals in this discursive order. It seems to be in the middle of the field of hospital's knowledge and Primary Care. SUS principles are invoked to support this kind of care, such as integrality, reference and counter-reference, substituted by the Health Care Network.

Home Care should be a care modality which is included in the local SUS health systems. Thus, it integrates the actions of the basic network, urgency and emergency and hospital area. [...] the request for inclusion in the program can range from basic care units, emergency care units or hospital care teams for teams [...]. When users are in the process of being discharged from the program, this responsibility will be transferred to the relevant sphere, i.e. primary care. In the case of escalations that are subject to a therapeutic intervention of greater intensity and density of care, these may, according to necessity, be transferred to their hospital unit [...]. The proposal of Home Hospitalization can act as a 'seam' between the hospital level and basic care [...]. The establishment of shared responsibility between different levels of the health service network becomes essential in order to ensure the continuity necessary 
to meet the needs of particularly vulnerable groups. Sharing responsibilities between equipment and teams makes sense, as it is a distinctive element of the station concept in the line of care (D3).

Art. $5^{\circ}$. Home Care should follow the following guidelines: I - be structured from the perspective of Heal th Care Networks, with basic care being the coordinator of care and territorial action; II - be incorporated into the regulation system, linking with the other points of attention to health and with rear services; III - be structured according to the principles of expanding access, reception, equity, humanization and integrality of assistance; IV - be inserted in lines of care by means of clinical practices based on user needs, reducing the fragmentation of care (D5).

Some issues, considered as fundamental and indispensable, are at stake, in this excerpt: shared responsibility (between services), continuity of care, health care network linked by services. This gives the SUS users a sense of security, since the State guarantees their health and their life, even if it prevents them from reaching the hospital, because they will receive assistance at their home. This strategy has effects on healthcare professionals, the impression that they assure patient care. My role here is not to say that home care does not work, but to bring things up, disperse things that have been said, and show how they organize to control the life of the population.

Regarding continuity of care, related to the integrality principle of SUS, guaranteed home care means those with chronic-degenerative conditions remain included in health care, remaining in this game of health imperative for all. Inclusion functions as a practice of governmentality, which makes people stay in the game, or rather, be included, which guarantees the condition of participation in biopolitical interventions. Inclusion functions as a biopolitical device because, once included in the groups, in the official registers, in the labor market, in the stock exchange-assistance, in school, people become easy targets of state actions. Such actions seek to conduct human conduct in a set of rules defined within the different social groups. I would also add the inclusion through health policies. Once people are in programs and in information systems, they are easily accessed, and their data will produce knowledge about these population groups. Doubling the interest of the State, to understand each person, and to produce knowledge in order to better govern them. ${ }^{26}$

Taking the emergency services as a condition of possibility for the appearance of home care, we rely on a document from the Ministry of Health, from 1965 , that explains how this service was organized.
Such services should not constitute isolated hospital units, since, attached to general hospitals, they expanded their field of action, benefiting the various neighborhoods where the hospitals were located. In addition, an emergency room service operating in a general hospital can count on hospital equipment and resources, both material and technical. The hospital would have the benefit of permanent staff to attend to urgent cases that occurred among the inpatients, as well as their own personnel. For out-of-hospital care, ambulances moved to the emergency room within their zone of action. ${ }^{27}$

The large cities were divided into zones and each of them were attended by one of these hospitals. In these places, the flow of care came from the call to the hospital, with the departure of the ambulance for the first resources and technical personnel. If the case could not be resolved on the spot, the doctor himself would accompany the patient to the hospital in the ambulance, providing emergency relief. ${ }^{27}$ Confronted with this, one can perceive that for a long time this institution worked behind closed doors, determining their demands. The patients went to the hospital when they were referred by doctors after an appointment or emergency. There was no "entrance point" for immediate care, as it exists in the present times, where the patient establishes the demand, which provides the evaluation for immediate care. The Estratégia Saúde da Família can also be considered a condition of possibility, once the "dream" of it being the entry door of entry has dissipated or will dissipate. Many studies show that the entry door is still the emergency room, the immediate care ${ }^{28-29}$ Perhaps for this reason the appearance of the health care network discourse is linked to the shared responsibility between services.

In this control society, it is desired that people take responsibility for the care of their family member. Governance is pulverized so that it is possible to govern oneself and others, composing home care as a security device. This device ensures the life of the population, especially the unproductive; it guarantees the imperative of health for all; and if not the most important, in this mesh of power, the role of the State as guardian of peace and order, in which acts as mediator of the interests of the people.

\section{CONCLUSION}

This study shows how home care is configured in a safety device that intends to keep sick people in their homes, proposing healthcare teams with hospital technology. This form of home care originates with the changes in the epidemiologi- 
cal profile of the population, which resulted in increased life expectancy and the occurrence of chronic-degenerative conditions. This fact led to important changes in health care, and also related to a possible hospital crisis as an institution. This situation has had an impact on health policies and institutions, leading hospitals to expand their services towards the patient's home, especially those who a cure is not possible. In this way, technology, human resources and materials were moved to this space, aiming to reduce hotel spending and provide space for patients in need of technology. In the analyzed documents, we observed that the crisis seems to be supported by discourses of humanization in health that oppose the technological model, centered on the doctor and the hospital. Considering these conditions of possibility for the home care event, we problematize how this knowledge is being organized by the State, which, in addition to inventing this modality of care, establishes its rules and finances, configuring it as a security device.

Home care as a safety device had chronic degenerative conditions as conditions of possibility for its appearance due to the increase in life expectancy coupled with the need to save the hospital space. Thus, the discourse constitutes the home as a safer and better place for the patient, who is at home, ie, close to the family, away from the risk of nosocomial infection, receiving care from a team that will provide the necessary technology. A safety device to govern the unproductive, making a patient's family member productive as a caregiver.

We emphasize that this was one of the possible analyzes, that other possibilities could be raised, aslong as there is no researcher neutrality in poststructuralist researches, which is intertwined with its researched object, in this case home care, and the factory of artisanal form. Also, we emphasize the impossibility of describing the totality of the home care object, since in Foucaultian studies, starting with the choices it is necessary to minimize some things, and to maximize others.

\section{REFERÊNCIAS}

1. Burns CM, Abernethy AP, Leblanc TW, Currow DC. What is the role of friends when contributing care at the end of life? Findings from an Australian population study. Psycho-oncology. 2011; 20(2):203-12.

2. Brobäck G, Berterö C. How next of kin experience palliative care of relatives at home. Eur J Cancer (Engl). 2013; 12(4):339-46.

3. Oliveira SG, Kruse MHL, Sartor SF, EchevarríaGuanilo ME. Enunciados sobre la atención domiciliaria en el panorama mundial: revisión narrativa. E-global. 2015 jul; 14(3):375-89.

4. Ministério da Saúde (BR). Portaria n. 2.527, de 27 de outubro de 2011: Redefine a Atenção Domiciliar no âmbito do Sistema Único de Saúde. Diário Oficial [da] República Federativa do Brasil. 28 out 2011. Seção 1;44-6.

5. Foucault M. O nascimento do hospital. In: Machado R, organizador. Microfísica do poder. 25 a ed. Rio de Janeiro: Graal; 2012. p.171-89.

6. Foucault M. O nascimento da medicina social. In: Machado R, organizador. Microfísica do poder. $25^{\mathrm{a}}$ ed. Rio de Janeiro: Graal; 2012. p.143-70.

7. Fonseca JPA. Normalização e bio-poder na obra de Michel Foucault. Theoria. 2012; 4(11):75-90.

8. Oliveira SG, Quintana AM, Budó MLD, Kruse MHL, Beuter M. Internação domiciliar e internação hospitalar: semelhanças e diferenças no olhar do cuidador familiar. Texto Context Enferm. 2012; 21(3):591-9.

9. Ishii Y, Miyashita M, Sato K, Ozawa T. A family's difficulties in caring for a cancer patient at the end of life at home in Japan. J Pain Symptom Manage. 2012 Oct; 44(4):552-62.

10. Foucault M. A arqueologia do saber. $8^{\text {a }}$ ed. Rio de Janeiro (RJ): Forense Universitária; 2013.

11. Foucault M. Nietzsche, a genealogia e a história In: Machado R, organizador. Microfísica do poder. $25^{\mathrm{a}}$ ed. Rio de Janeiro (RJ): Graal; 2012.p. 55-86.

12. Dreyfus HL, Rabinow P. A genealogia do indivíduo moderno: a analítica interpretativa do poder, da verdade e do corpo. In: Dreyfus HL, organizador. Michel Foucault: uma trajetória filosófica para além do estruturalismo e da hermenêutica. $2^{\text {a }}$ ed. Rio de Janeiro (RJ): Forense Universitária; 2010.p.188-220.

13. Foucault M. Verdade e poder. In: Machado R, organizador. Microfísica do poder. $25^{\mathrm{a}}$ ed. Rio de Janeiro (RJ): Graal; 2012. p.34-54.

14. Foucault M. Em defesa da sociedade: curso dado no College de France (1975-1976). São Paulo (SP): Martins Fontes; 2005.

15. Foucault M. Sobre a história da sexualidade. In: Machado R. Microfísica do poder. 25a ed. Rio de Janeiro (RJ): Graal; 2012. p. 363-406.

16. Foucault M. O que é um autor? In: Motta MB, organizador. Ditos e escritos: estética - literatura e pintura, música e cinema (vol. III). $3^{\text {a }}$ ed. Rio de Janeiro (RJ): Forense Universitária; 2006. p.264-98.

17. Oliveira SG, Quintana AM, Budó MLD, Morais NA, Garcia RP, Sartor SF, et al. Internação domiciliar na terminalidade: escolhas terapêuticas e medidas de conforto no olhar do cuidador. J Nurs Health [Internet]. 2013 [cited 2014 ago 20]; 3(2):221-32. Available from: http:/ / periodicos.ufpel.edu.br/ojs2/ index.php/enfermagem/article/viewFile/3731/3300

18. Alencar VA. Contribuições da internação domiciliar para promover a desospitalização e prevenir a 
reospitalização no âmbito doSUS Brasília [Dissertação]. Brasília (DF): Universidade de Brasília, Programa de Pós-Graduação em Enfermagem; 2013.

19. Cordeiro FR. Eu decido meu fim? A mídia e a produção de sujeitos que governam a sua morte [dissertação]. Porto Alegre (RS): Universidade Federal do Rio Grande do Sul, Programa de Pós-Graduação em Enfermagem; 2013.

20. Oliveira CP, Kruse MHL. A humanização e seus múltiplos discursos: análise a partir da REBEn. Rev Bras Enferm. 2006; 59(1):78-83.

21. Deleuze G. Conversações. São Paulo (SP): Editora 34; 1992.

22. Ministério da Saúde (BR). Manual instrutivo do Melhor em Casa: a segurança do hospital no conforto do seu lar. Brasília (DF): MS; 2011.

23. Makoae MG, Jubber K. Confidentiality or continuity? family caregivers' experiences with care for HIV/ AIDS patients in home-based care in Lesotho. SAHARA J. 2008; 5(1):36-46.
24. Foucault M. O nascimento da clínica. $7^{\mathrm{a}}$ ed. Rio de Janeiro (RJ): Forense-Universitária; 2015.

25. Kuo C, Operario D, Cluver L. Depression among carers of AIDS-orphaned and other-orphaned children in Umlazi Township, South Africa. Global Public Health. 2012; 7(3):253-60.

26. Lopes MC, Rech TL. Inclusão, biopolítica e educação. Educação. 2013; 36(2):210-9.

27. Ministério da Saúde (BR). Departamento Nacional de Saúde. Divisão de Organização Hospitalar. História e evolução dos hospitais. $2^{\mathrm{a}}$ ed. Rio de Janeiro (RJ): MS; 1965.

28. Campos RTO, Ferrer AL, Gama CAP, Campos GWS, Trapé TL, Dantas DV. Avaliação da qualidade do acesso na atenção primária de uma grande cidade brasileira na perspectiva dos usuários. Saude Debate. 2014; 38:252-64.

29. Nonnenmacher CL, Weiller TH, Oliveira SG. Acesso à saúde: limites vivenciados por usuários do SUS na obtenção de um direito. Ciencia Cuid Saude. 2011 Abr-Jun; 10(2):248-55.
Correspondence: Stefanie Griebeler Oliveira

Universidade Federal de Pelotas - Enfermagem

Rua Gomes Carneiro, n.1

96090-640 - Pelotas RS, Brasil

E-mail: stefaniegriebeleroliveira@gmail.com
Received: June 30, 2015

Approved: September 25, 2015 